\title{
CITAČNÍ ETIKA \\ V PEDAGOGICKÉM VÝZKUMU: \\ K VYNUCOVÁNÍ CITACÍ \\ A ZAKLÁDÁNÍ CITAČNÍCH KARTELŮ
}

\author{
CITATION ETHICS IN EDUCATIONAL \\ RESEARCH: ON COERCING CITATIONS \\ AND ESTABLISHING CITATION CARTELS
}

\author{
PETR KNECHT, FRANTIŠEK TŮMA
}

\begin{abstract}
Abstrakt
Ačkoli počty citaci json považovány zejména za indikátory reputace a prínosnosti vědcu v akademické komunitè, mohou nabývat také určité ekonomické hodnoty. Tento ekonomizujici prìstup je možné pozorovat

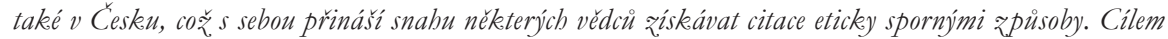
studie tedy je podrobnèji pojednat o problematice citování. Vybrané ukázky, keteré vycházejí z vlastni akademické zkušenosti a pozorováni obou autorü, dokumentuji, jak akademici vynucuji citace a zakládají citační kartely. Z pobledu Mertonova védeckébo étosu tyto praktiky vedou k rozkladu nezaujatosti, transparentnosti a kritického pròstupu ve védè. V závèru uvádíme vybraná doporučení pro eticky správné citování.
\end{abstract}

Klíčová slova

védecká etika, publikačni etika, sporné védecké postupy, citace, vynucené citace, citační bratrstva, citační kartely

\begin{abstract}
Although numbers of citations are considered to be indicators of a researcher's reputation and contributions in academia, citations can also be assigned a certain economic value. This economic approach can be observed in Czechia, too, which motivates some researchers to gain citations using ethically problematic methods. Therefore, the aim of this study is to discuss issues related to citations. Selected excerpts, which originate from the authors' academic experience and observations, document how researchers coerce citations and establish citation cartels. Viewed from the perspective of Merton's scientific ethos, these practices undermine openmindedness, transparency, and a critical approach in research. We present some recommendations for ethically correct citations in the conclusion of this paper.
\end{abstract}

Keywords

etbics of science, publication ethics, questionable research practices, citations, coercive citations, citation cartels 


\section{Úvodem: proč se zabývat zrovna citacemi?}

Aktuální vývoj vědní politiky v Česku naznačuje, že končí období hodnocení vědeckých publikací dle počtu publikovaných výstupů $\mathrm{v}$ př́slušných „započitatelných“ kategoriích. Jednoduchý „kafemlejnkový“ indikátor postupně začíná být nahrazován indexem Article Influence Score (Metodika..., 2017, s. 21), který na základě citačních ohlasů jednotlivých textů zařazených v databázi Web of Science umožňuje následně vytvořit „,kvalitativni““ publikační profil hodnocených institucí i oborů, a v neposlední řadě také jednotlivých vědců. Předpokládá se, že podrobnější citační analýzy se v blízké budoucnosti stanou běžnou součástí bibliometrického hodnocení vědy v Česku (Úřad vlády, 2020). Vykazování počtů citací se zároveň stalo nedílnou součástí žádostí o granty (např. v žádostech o financování základního výzkumu podávaných Grantové agentuře České republiky), formulářů $\mathrm{k}$ habilitačnímu a jmenovacímu řízení, a také personálních listů v žádostech o akreditace studijních programů. Citace také stojí v pozadí citačních metrik vztahujících se k vlivnosti časopisu, jako jsou např́ílad impaktový faktor (Web of Science) nebo indexy CiteScore, SJR a SNIP (Scopus). Na základě citačních metrik se utvářejí žebříčky časopisů (např. rozdělení do kvartilů podle impaktového faktoru), vědců (napr. h-index, příp. informace o nejcitovanějších autorech $\mathrm{v}$ dané zemi či instituci) nebo univerzit (např. QS World University Rankings). Přestože zavádění metrik má svá četná úskalí, jsou (nejen) v akademické sféře hojně používané, např́iklad proto, že umožňují nahrazovat odborný úsudek numerickými indikátory, mohou být transparentní a relativně snadno dostupné (Muller, 2020).

Všechny výše uvedené metriky mají společné to, že jsou odvozeny od počtů citací. I díky tomu se začíná problematika eticky zodpovědného citování čím dál častěji objevovat také na úrovni institucionálních politik univerzit či jiných vědeckých organizací (srov. nap̌r. Petr, 2017). Ačkoli se všeobecně předpokládá, že vyšší počet citací dokládá vysokou vědeckou hodnotu díla, nebot' toto dílo vzbudilo četné pozitivní ohlasy v komunitě vědců (Aksnes \& Rip, 2009)ํㅜㄹ citování nepovažujeme za zcela neutrální akt, nebot’ citace mohou nabývat také strategické či směnné hodnoty. V pozadí citování

Z tohoto předpokladu vycházejí četné bibliometrické analýzy různých vědních oborů (exemplárně nap̌r. Bezdíček, Preiss, \& Dočkalová, 2009, pro psychologii; Kouba, 2011, za politologii; Bajerski \& Siwek, 2012, pro geografii; Skovajsa, 2014, pro sociologii; Juhaňák, 2017, nebo Průcha, 2015, za pedagogiku; Tomančáková, 2015, pro informační vědu a knihovnictví apod.). Zmíněné analýzy si většinou kladou za cíl nalézt tzv. jádro oboru, tedy nejcitovanějšŕ časopisy, publikace a vědce. 
totiž mohou být i jiné než čistě věcné motivy, např́klad snaha zalíbit se nadř́zenému, pravděpodobnému recenzentovi nebo editorovi časopisu (Fong \& Wilhite, 2017). Problematické je také rozhodnutí záměrně necitovat vědce, se kterým si autor lidsky „,nesedl“, př́ípadně vědce, který může být přímým konkurentem v kompetitivním prostředí vědy (Reedijk, 2012). Častým terčem kritiky bývají také recenzenti, kteří mají tendenci doporučovat autorům článků, aby citovali jejich práce primárně za účelem navýšení citačních indexů, což může být vnímáno jako eticky sporná manifestace moci (Thombs et al., 2015). Tento psychologický pohled na citování však má své limity - jak uvádí Nicolaisen (2007, s. 615), analýzy motivů pro (ne)citování trpí zásadním nedostatkem, že autoři si obvykle nejsou plně vědomi toho, proč citují právě daný zdroj a ne jiný; značnou roli zde hraje také prostředí, kde autor působí.

Cílem naší studie je na pozadí obecnějších zásad publikační etiky popsat dvě praktiky související s citováním: vynucování citací a zakládání citačních kartelů. Jak ukážeme dále, zmíněné praktiky jsou zpravidla označovány jako eticky sporné. S oporou o odbornou literaturu a vybrané ukázky vycházející z našeho dosavadního akademického působení a zkušeností v oblasti pedagogických věd $s$ přesahem do geografie ( $v$ př́ípadě prvního autora) a lingvistiky (v př́padě autora druhého) vyvozujeme, že používání eticky sporných citačních praktik může mít řadu negativních dopadů. Vedlejším cílem studie je zvýšit citlivost čtenářů $\mathrm{k}$ takovému eticky spornému jednání v oblasti citování. V závěru studie proto uvádíme vybraná doporučení pro eticky správné citování.

\section{Citování jako nepř́liš rozpracovaná a málo uvědomovaná oblast publikační etiky}

Ve studii rozpracováváme část příspěvku o problematických stránkách citování, který jsme přednesli na konferenci České asociace pedagogického výzkumu v Českých Budějovicích v roce 2016. Abychom ukázali na závažnost tematiky eticky správného citování, začneme krátkou ukázkou zachycující reakci publika na náš př́spěvek.

Ukázka 1: V prezentaci jsme mimo jiné pojednali o citačních kartelech a ukázali př́klad umělého navyšování impaktového faktoru časopisu. V následné diskusi zazněl z pléna dotaz od členky redakční rady jednoho z předních českých pedagogických časopisů, zda by se české časopisy neměly dohodnout na tom, že se začnou více vzájemně citovat, aby mohly být zařazeny do databází a aby se zvýšily jejich citační indexy.

Ukázka naznačuje, že se nám $v$ prezentaci zřejmě nepodařilo dostatečně akcentovat nebezpečné dopady existence citačních kartelů: tyto kartely jsme sice problematizovali (ostatně samotné slovo kartel má negativní konotaci), nicméně dotaz členky redakční rady jednoho z časopisů lze interpretovat 
spíše jako pobídku k založení českého pedagogického citačního kartelu. Téměř tři roky poté, co jsme vystoupili s př́spěvkem na výše zmíněné konferenci, jsme dospěli k rozhodnutí pojednat o fenoménu citování formou časopisecké studie. Během těchto tř́ let jsme zvýšili svou citlivost k citačním praktikám a citačnímu chování vědců, se kterými jsme byli v kontaktu ( $\mathrm{k}$ výchozím datům a metodologickým aspektům viz níže). Uvědomili jsme si, že vynucování citací a zakládání citačních kartelů jsou v akademickém prostř̌edí běžně pozorovatelné a zároveň málo problematizované praktiky. Vědci navíc své prohřešky vůči publikační etice často omlouvají či bagatelizují nízkým povědomím o zásadách eticky správného jednání. ${ }^{2}$ Proto začneme zeširoka od východisek publikační etiky.

Etika je filozofická disciplína, která se zabývá morálkou nebo morálně relevantním jednáním a jeho normami. Z definice etiky taktéž vyplývá, že etické normy jsou dynamické a vyvíjejí se v čase spolu s tím, jak se vyvijí prostředí, které tyto normy zpětně uplatňuje. Etické kodexy, tj. materializované soupisy pravidel vhodného/žádoucího jednání na úrovni vědeckých společností, akademických institucí či vědeckých časopisů, mají spíše apelativní charakter, který vymezuje obecná pravidla pro jednání vědců bez jejich hlubšího a právně vymahatelného exaktního výkladu. Většina těchto kodexů v oblasti vědecké etiky explicitně pojednává o plagiátorství, falšování a zkreslování výzkumných zjištění, střetu zájmů nebo ochraně účastníků výzkumu. Prohřrešky v těchto oblastech jsou považovány za hrubé porušení etiky vědecké práce. $V$ př́padě vyslovení podezření či nařčení z porušení etických norem následné právní spory většinou vyznívají do ztracena - jako př́́klad lze zmínit problematiku odebírání vysokoškolských titulů př́i plagiátorství u diplomových prací. Etické kodexy tedy v jistém ohledu selhávají, nebot' stanovit naprosto přesná, závazná, univerzální, nadčasová a vymahatelná pravidla pro vykonávání vědecké práce je zkrátka obtížné. Není proto překvapivé, že ačkoli se většina vědeckých časopisů i nakladatelství explicitně hlásí k dodržování zásad publikační etiky, což je zároveň také podmínkou zařazení do některých služeb a databází (nap̌r. Scopus), mnozí vědci přiznávají, že některé ze zásad publikační etiky vědomě porušují (Grant et al., 2018).

2 Dokladem pro toto zjištění může být např́iklad pohled na web spolku Věda žije! (http:// www.vedazije.cz). Z let 2018 a 2019 se zde objevují texty s titulky jako nap̌r. „Otevřený dopis rektorovi UK T. Zimovi ve věci údajného plagiátorství prof. Kováře“, „Kdo může za opsané diplomky“, „Otevřený dopis rektorovi Univerzity Tomáše Bati ve Zlíně ve věci údajného plagiátorství Petra Krčála“, „Otevřený dopis rektorce Mendelovy univerzity od vědců a vědkyň Fóra Věda žije!"ve věci podezření na plagiátorství Tat’ány Malé, „FSV UK: Bude spoluautorka Wadima Strielkowského docentkou?“. Tato iniciativa a další kauzy poukazují na velmi slabé povědomí o publikační etice v Česku. 
Nutno podotknout, že oblast správného citování většinou zưstává v etických kodexech nepokryta. ${ }^{3}$ Citování tak spadá do „šedé zóny“ (Artino, Driessen, \& Maggio, 2019), jejíž existence někteří lidé šikovně využívají, nebot' zde existuje značný prostor pro racionalizaci eticky sporného jednání a sebeklam (John, Loewenstein, \& Prelec, 2012). Patrně ani není možné očekávat, že etické kodexy vědeckých institucí či vědeckých společností budou na dynamický vývoj v oblasti uplatňování eticky sporných vědeckých postupů stejně pružně reagovat. Na př́íkladu Etického kodexu České asociace pedagogického výzkumu je možné doložit, že od předložení jeho první verze (Průcha \& Švaříček, 2009) po schválení jeho definitivního znění uplynuly téměř čtyři roky. Publikační etika, stejně jako kterákoli jiná oblast vědecké etiky, je prredmětem neustálé diskuse, do níž touto studií prrispíváme.

\section{Mertonův vědecký étos jako etalon kultury poctivých vědců}

Než přistoupíme k citacím, považujeme za nutné projasnit naše teoretické pozice. S oporou v Aristotelovi (1996) zdůrazňujeme roli výchovy a zvyků při získávání charakterových ctností. Ctnostným se člověk stane tím, že se před ním ctnostně jedná. Etika je tedy spjata s mezilidským jednáním. Zde se zaměříme na vědeckou práci, o jejíž podstatě pojednává americký sociolog R. K. Merton (1973), který definoval vědu jako svébytné uzavřené společenství utvářené dodržováním základních institucionalizovaných norem spočívajících v nestrannosti, transparentnosti, kritické reflexi a oddanosti čistě vědeckým zájmům. Takové pojetí vědy lze postavit do protikladu $\mathrm{k}$ utilitaristickým pojetím vědy vycházejícím z myšlenek J. Benthama (1996), jenž zdůrazňoval, že jednání lidí je motivováno pouze dvěma věcmi: maximalizací potěšení a minimalizací bolesti. Dobré jednání je dle Benthama takové, které přináší co největšímu počtu lidí potěšení a současně způsobuje co nejmenšímu počtu lidí bolest. Gaus (2003) dokonce připouští, že je legitimní „ušpinit si ruce“ $v$ př́padě, že je nutné zpronevěřit se některým etickým normám, pakliže je to jednání nutné pro blaho většího celku. Přestože v Benthamovi je možné nalézt legitimizaci eticky sporného jednání, které může být pro vědce ekonomicky či jinak výhodné (Stocker, 1992), hlásíme se zde k Mertonově pozici, ke které se budeme dále vztahovat při rozboru

\footnotetext{
Např́klad Etický kodex České asociace pedagogického výzkumu se problematikou citací v oddíle $\mathrm{k}$ publikační činnosti zabývá spíše formálně: výzkumník má uvádět pouze ty prameny, se kterými se skutečně seznámil (bod 6), dodržovat autorská práva (body 7 a 10), důsledně citovat i diplomové a jiné studentské práce (bod 8) a dodržovat pravidla citací podle zásad zavedených citačních norem (bod 9).
} 
vynucování citací a zakládání citačních kartelů. Tato pozice nám zároveň umožňuje vztáhnout problematizované praktiky $\mathrm{k}$ degradaci vědy na mechanické řemeslo a tržně orientovaný způsob obživy.

Z Mertonovy pozice můžeme zpochybnit názor některých vědců, že manipulace s citacemi nikomu neškodí, nebot' se tím nikomu neubližuje. Ve světle výše uvedeného je zř́ejmé, že pokud autor naprŕíklad cituje práci, která nijak neovlivnila vznik a podobu vlastního textu, dochází k podrývání nestrannosti, transparentnosti a kritické reflexe $\mathrm{v}$ dané oblasti. Citace totiž bude budit zdání, že citované dílo je věcně pro citující text nějak důležité, a tak může dojít $\mathrm{k}$ neprrirozenému navýšení hodnoty citovaného díla, a potažmo tedy i citovaného autora, který tak získá citaci. Mưže také dojít k umělému zlepšení pozice citovaného časopisu, jemuž taková citace může navýšit citační index (nap̌r. impaktový faktor). Tím se do vědecké práce dostávajî ekonomické, osobní nebo mocenské zájmy na úkor vědeckých zájmů. Je tedy zřejmé, že citace a jejich produkce prèedstavují ve sfére akademického psaní velmi komplexní výzkumnou oblast.

\section{Citace jako předmět výzkumu}

Držíme se Hylandova (2004) sociálního pohledu na tvorbu akademických textů, podle něhož aktéři (tj. editoři, recenzenti a čtenáři) při čtení akademického textu interpretují cíle a východiska autora, a zároveň, zejména před publikováním textu, mohou tito aktérí (zejména z pozice editorů a recenzentů) do značné míry do tvorby textu vstoupit. Na druhou stranu je to autor, kdo při psaní textu své pozice sdílí a kdo do značné míry předjímá, jak jeho text může být interpretován, a podle toho svůj text může koncipovat.

Citování v publikačním procesu lze nahlížet optikou různých disciplín (Tahamtan \& Bornmann, 2019). Zatímco sociolog se zaměří např́klad na utváření znalostí v textových a mezitextových vztazích, ústředním bodem zájmu lingvisty budou spíše jazykové prostředky, které autoři při citování používají, kdežto informatika budou zajímat bibliometrické údaje. Do hry také vstupuje vědní politika (hodnocení), která přirozeně ovlivňuje publikační priority a vzorce. ${ }^{4} \mathrm{~V}$ těchto různých pohledech se odráží také pojetí toho,

Ačkoli to zřejmě není žádoucím cílem, nastavení vědní politiky se zprostř̌edkovaně promítá také v chování vydavatelů či editorů, nebot' také oni chtějí se svými knihami či časopisy obstát $\mathrm{v}$ nějak nastaveném publikačním prostředí. Zařazení časopisu např́iklad do databáze Web of Science mủže být vnímáno jako známka prestiže. V neposlední řadě vědní politika nepřímo ovlivňuje také chování recenzentů např́klad tím, že recenzent může volit, zda s ohledem na vysokou či nízkou prestiž vydavatele či časopisu přijme text k posouzení. 
co je to citace, jak může být realizována a jaký má význam (k teorii citování viz např. Hyland, 2004, s. 20-40; Nicolaisen, 2007), přičemž zde se zaměř́me především na etické aspekty, které souvisejí s těmito různými perspektivami. S vědomím toho, že existují značné rozdíly mezi jednotlivými vědeckými disciplínami, a to jak z pohledu akademiků (např. Hyland, 1999), tak studentů učících se psát odborné texty (Swales, 2014), se zde zaměřujeme především na oblast pedagogiky, $\mathrm{v}$ níž máme sami řadu zkušeností především z pozic autorů, editorů, členů redakčních rad a členů odborných společností.

Počty publikačních výsledků i citací jsou často ovlivněny metodikou, která je k jejich hodnocení uplatňována (Stöckelová, 2009). ${ }^{5}$ Etické aspekty vystupují na povrch především tehdy, když si uvědomíme, že při hodnocení vědecké práce mnohdy dochází k „,redukci kvality na citační ohlas“" (Dvořáčková et al., 2014, s. 186). Jednotliví vědci, členové redakčních rad, vedení kateder a výzkumných skupin totiž bývají oceňováni za to, že jsou citováni, a pokud naopak nejsou, může to být překážkou v kariérním růstu jednotlivce, př́ípadně rozvoji či financování časopisu, pracovišstě nebo skupiny. Citace se tak stávají komoditou, která může být dále směňována (srov. Engeström, 2015, s. 67-70).

Důležitost etických aspektů citování dále vystupuje po zvážení některých informačně vědních zjištění. ${ }^{6}$ Bylo zjištěno, že 80 \% veškerých citací odkazuje k 20 \% veškerých článků (Garfield, 2006). Přehledové články, články v určitých vědních oborech (např. fyzika), články v angličtině a články s větším množstvím autorů bývají častěji citovány (Aksnes \& Rip, 2009; Hirsch, 2005). Stejní autoři v souvislosti s citovaností textů upozorňují na platnost tzv. Matoušova efektu, kdy články s vysokým počtem citací jsou citovány častěji než málo citované články. Starší studie ukazuje, že většina pracovníků univerzit nezíská za celou svou kariéru více než tř́i citace (Phelan, 1999). Zjištění z těchto analýz lze číst i tak, že mnoho článků z nejrůznějších důvodů prostě citováno není, a jejich autoři mohou hledat cesty, jak citace získat jinak. Možné prrístupy, jak překonat profesní nejistotu vyplývající z tlaku

$5 \quad$ V ekonomii se zmíněný jev označuje jako Goodhartovo pravidlo. Pokud se zaměříme na určitý indikátor a povýšíme ho na cíl našeho snažení, okamžitě se sníží síla jeho vypovídací hodnoty. Platnost pravidla potvrzuje analýza rapidně zvýšené citovanosti italských vědců záhy poté, co byla vyšší citovanost zavedena jako jedna z podmínek kariérního růstu na univerzitách v Itálii (Baccini, De Nicolao, \& Petrovich, 2019).

6 Pro zájemce o obsáhlejší analýzy dat z citačních databází odkazujeme na časopisy, které se tématu dlouhodobě věnují (Journal of Informetrics, Scientometrics, Social Studies of Science aj.).

7 Název je odvozen od biblického výroku svatého Matouše: „Nebot’ každému, kdo má, bude dáno; kdo nemá, tomu bude odňato i to, co má.“ Tento jev byl v prostředí vědy zpopularizovaný a pojmenovaný Mertonem (1968). 
vytvářeného citačními indexy, identifikoval Haley (2017). První přístup spočívá v pasivní rezistenci, kdy publikující vědec čeká a doufá, že ho někdo bude citovat. Druhý př́istup je založen na tom, že se autor začne věnovat citačně atraktivním tématům, př́padně změní obor své působnosti. Třetím př́stupem je začít vynucovat citace od kolegů nebo s nimi založit citační kartel (a současně v textech uvádět hodně autocitací pro zvýšení kýženého efektu), čímž je možné, jak ukážeme dále, naplnit požadované citační indikátory. Třetí cesta se může jevit jako nejrychlejší, ale současně také eticky značně sporná, a proto se na ni zde zaměŕíme.

\section{Poznámky k metodě}

Naší motivací k sepsání této studie byla řada momentů, kdy jsme se setkali s eticky sporným publikačním jednáním. Sdílíme vědecký zájem a přesvědčení, že vědecká práce by měla být transparentní, nestranná a kritická (Merton, 1973), což v nás v řadě situací vyvolalo silný vnitřní konflikt, díky kterému jsme následně byli schopni situaci zaznamenat formou pracovních poznámek (srov. Sannino, 2008). Tyto poznámky jsme pro účely zde prezentované analýzy doplnili vybranými úryvky ze svých e-mailových korespondencí s jednotlivci nebo redakcemi časopisů, které souvisely s citováním. $\mathrm{V}$ tomto ohledu stavíme na prvcích autoetnografického př́stupu, nebot' jako autoři prŕspěvku (a) jsme plnohodnotnou součástí prostředí, které pozorujeme, (b) naši pozici v této studii otevřeně přiznáváme, (c) usilujeme o teoretizaci a hlubší pochopení prríčin, projevů a důsledků sledovaných sociálních jevů (Anderson, 2006, s. 373). Konkrétně jsme se při procházení jednotlivých epizod v našich datech zaměřovali na praktiky, kterými různí členové vědecké komunity produkují citace proti mertonovskému étosu. Praktikami rozumíme v souladu s etnografií (Atkinson \& Hammersley, 2007, s. 168-171), etnometodologií a konverzační analýzou (Auer, 2014, s. 135) pozorovatelné způsoby jednání, kterými lidé provádějí různé úkony.

Při procházení našich poznámek, e-mailů a při řadě neformálních rozhovorů s kolegy jsme rozkryli řadu praktik, kterými se různí akademici nějakým způsobem vztahovali k produkování citací. $V$ této studii se zaměříme na dvě hojně zastoupené praktiky: vynucování citací a zakládání citačních kartelů. Stranou ponecháváme problematiku autocitací, nebot' prestižní vědecké databáze aktuálně disponují nástroji, jak autocitace na úrovni jednotlivců i časopisů z citačních metrik relativně snadno odfiltrovat (Lăzăroiu, 2013).

Jsme si vědomi limitů, které výše uvedený postup prrináší. Jde zejména o to, že zastáváme pozici odlišnou od protagonistů z epizod, které ve studii rozebíráme, nicméně svůj pohled na citační praktiky zde reflektujeme. Druhým výrazným limitem je skutečnost, že vycházíme z osobních zkušeností a zpráv 
ze svých e-mailových schránek. V ukázkách proto popisujeme pozorované praktiky co nejkonkrétněji, zároveň však kvưli ochraně soukromí protagonistů všechny ukázky uvádíme v anonymizované podobě. Naše zdroje dat (terénní poznámky, e-maily), ve kterých se eticky sporné publikační praktiky vyskytují, znemožňují přesnou kvantifikaci zachycených jevů ani odhad četnosti jejich výskytu v akademické komunitě, nicméně, jak uvádí Psathas (1995, s. 50), i jediný výskyt postačuje k tomu, aby bylo možné analyzovat, jak byla daná praktika produkována, včetně dostupnosti prostředků nezbytných pro produkci předmětného jednání a způsobilosti aktérů $\mathrm{k}$ takovému jednání. Díky tomu je možné a také pravděpodobné, že se daná praktika bude opakovat.

V následujících oddílech pojednáme o dvou typech eticky sporných praktik, které jsme identifikovali: vynucování citací a zakládání citačních kartelů. Pro každou z těchto praktik uvádíme několik typických ukázek, které podrobně rozebíráme a následně s oporou o odbornou literaturu diskutujeme o širších souvislostech, dalších možných projevech, dopadech na komunitu a o možných řešeních.

\section{Vynucování citací}

Jeden ze spoluautorů této studie rozeslal svou knihu na pedagogická pracoviště v Česku. Publikace byla vydána z grantových prostředků, a tudíž byla neprodejná; její rozeslání bylo motivováno diseminací výsledků tříletého bádání. Zanedlouho autor publikace obdržel krátký e-mail od jednoho z kolegů, ve kterém stálo:

Ukázka 2: Hlavně nerozumím tomu, proč nikde neuvádíš odkazy na práce našeho týmu. Myslím, že jsme jak v českém, tak anglickém jazyce publikovali naprosto vynikající práce na téma [anonymizováno]. Proto se chci zeptat, proč texty necituješ.

E-mail představuje běžný komunikační prostředek, kterým lze v př́padě obdržení odborné publikace autorovi poděkovat, př́ípadně zhodnotit zaslanou publikaci. Z volby krajních výrazů („,nikde neuvádíš“, „jsme publikovali naprosto vynikajicí práce") lze usuzovat na značnou míru znepokojení odesílatele, a závěrečnou otázku, která na předchozí věty navazuje, lze číst spíše jako výčitku než jako dotaz na důvody necitování prací daného autorského kolektivu. Místo toho, aby se odesílatel vztahoval k věcné hodnotě monografie (tj. k poznání, které kniha přináší) a jejímu případnému hodnocení,

8 Odesílatel neuvádí žádné konkrétní dílo ani myšlenku, která by doložila, že opomenutím citace mohlo dojít ke snížení vědecké hodnoty diskutovaného díla, v e-mailu chybí jakékoli další zdůvodnění požadavku. Připouštíme, že součástí vědecké práce často bývají i omyly a opomenutí z nevědomosti; e-maily upozorňující na chyby, stejně jako následnou snahu o jejich nápravu, proto považujeme za naprosto žádoucí. 
se odesílatel ve svém e-mailu pozorovatelně vztahuje k citacím jako ke komoditě, jejíž zisk může být pro jeho tým potenciálně přínosný. Dlužno podotknout, že diskutovaná kniha na relevantních místech práce dotčeného týmu cituje, nicméně zřejmě ne v míře, která by odesílatele e-mailu uspokojila.

O motivaci odesílatele e-mailu lze jen spekulovat. Je možné, že odesílatel usiloval o zisk většího uznání ze strany autora monografie, nebot' také ve vědě platí Bourdieuho teze, že mít ohlas $\mathrm{v}$ poli znamená $\mathrm{v}$ něm existovat (Bourdieu, 2010, s. 296). Vedle uspokojení z objevu nějakého zásadního výzkumného zjišsění může být pro některé vědce hlavní motivací a současně odměnou respekt a uznání ze strany kolegů z oboru, což se může materializovat i v citacích.

Př́pad uvedený v ukázce 2 zdaleka není ojedinělý. Druhý spoluautor měl podobnou zkušenost, rovněž při distribuci své knihy vydané $\mathrm{v}$ rámci řešení tř́letého grantového projektu. V ukázce 3 se jedná o setkání tváří v tvář na konferenci:

Ukázka 3: Kolegyně, která na konferenci právě osobně od autora dostala výtisk nové knihy, poděkovala a začala knihou rychle listovat. Když se dostala k zadní části knihy se soupisem literatury, začala knihu pečlivěji studovat a po chvíli bez dalšího komentáře smutně konstatovala: „To je škoda, že mě necituješ.“

Způsob, jakým obdarovaná osoba listovala knihou, potvrzuje zjištění uvedené výše: spiše než na věcnou stránku knihy se pozorovatelně zaměřuje na soupis citované literatury; v následné replice toto zaměření dále zúží na absenci citací své osoby v soupisu literatury. ${ }^{9}$ Repliku by v izolaci šlo číst jako pouhé postesknutí, nicméně s ohledem na způsob manipulace s knihou a pozorovatelné zaměření na seznam literatury se přikláníme spíše k interpretaci dané repliky jako výčitky. Podobně jako v ukázce 2 i zde můžeme pozorovat, že citace se stávají komoditou, která je v komunitě od kolegů požadována, a její absence je sankcionovatelná uvedenými výčitkami.

Jeden z recenzentů otevřel otázku, zda si autoři rozdáváním svých knih neř́kají o citace. Zde je třeba přiznat, že vědci nebo jejich mateřské instituce často sami propagují výsledky své vědecké práce s cílem šírít publikované poznatky a zaujmout potenciální čtenáře - děje se tak nejen skrze rozesílání publikací, ale také prostřednictvím propagace publikací na sociálních sítích, v elektronickém podpisu e-mailu apod. Někteří autoři tak mohou činit z entuziasmu a zájmu rozvíjet obor, případně z obavy, aby jejich dílo nezůstalo ztraceno $\mathrm{v}$ hromadě publikačního balastu, jiní mohou své publikace

9 V případě obdarování tváří v tvář by bylo možné uvažovat také o estetické stránce, kterou lze zhodnotit relativně rychle pohledem na obálku knihy (ke skládání komplimentů v češtině viz Dvořáková, 2017). 
propagovat pragmaticky s vidinou zisku citací. At' je motivace v pozadí jakákoliv, samotný akt rozeslání nebo věnování publikace považujeme za součást šíření výsledků bádání, přičemž předpokládáme, že před př́padným citováním se obdarovaný s publikací seznámí a vyhodnotí její kvality a relevanci ke své práci. $\mathrm{K}$ tomu je nutné dodat, že by $\mathrm{v}$ těchto situacích neměl zaznívat požadavek či prosba k následnému citování. Rozhodnutí, zda citovat či necitovat, musí učinit každý autor sám v závislosti na tom, zda publikaci při psaní článku či realizaci výzkumu použil.

Ukázky 2 a 3 naznačují, že existuje určitý normativní požadavek na citování prací jiných akademiků. Jako autoři jsme se s tímto požadavkem setkali až po vydání knih $\mathrm{v}$ podobě sankce za necitování děl, která jsme v publikacích nepoužili, nicméně existuje celá řada prrípadů, kdy jsou autoři k citování určitých textů nuceni již při koncipování svého rukopisu, jak dokládá anonymizovaný úryvek z úvodníku jednoho časopisu vydávaného [anonymizováno] univerzitou:

Ukázka 4: Vzhledem k důležitosti citací pro [anonymizováno] uvádějte v co nejvyšší míre v soupisech literatury na konci svých textů odkazy na články zveřejněné v uplynulém desetiletí na stránkách [anonymizováno]. Prospějete časopisu [anonymizováno] i sobě.

Protože se jedná o informaci pro budoucí autory, není zde požadavek na citování určitých textů (zde z okruhu článků z daného časopisu vydaných v posledních deseti letech) formulován jako výčitka, ale jako př́kaz („uvádějte") zdůvodněný důležitostí citací a prospěšností pro časopis i samotné autory. Zmíněná prospěšnost má patrně spočívat $\mathrm{v}$ tom, že budou-li autoři „V co nejvyšší míře “ citovat daný časopis, dojde k navýšení citačních ohlasů, a tudíž se zvýší šance na zařazení časopisu do některé z prestižních citačních databází. Zařazením časopisu do citačních databází může následně dojít k navýšení finančních prostředků, které mateřská instituce (a prostřednictvím vnitroinstitucionálních pravidel financování také pracoviště autora, a někdy i autor sám) obdrží za vykázání publikovaného článku v takovém časopise. Tím, že bude časopis zařazen do některé z prestižních citačních databází, může být pro publikující autory snazší naplnit kritéria stanovená pro zvýšení akademických kvalifikací. Podobně jako v předchozích ukázkách i zde dochází ke komodifikaci citací.

Za zmínku stojí také dva aspekty, které $\mathrm{v}$ uvedeném úryvku viditelně absentují. Zaprvé si všímáme, že se zde zcela vytratila užitná hodnota citací, tedy že citováním autoři podporují nějaký argument, vyjadřují souhlas nebo nesouhlas s odkazovaným textem apod. (srov. s typologií citací u autorů Chubin \& Moitra, 1975, srov. také s normativní teorií citování, podle níž citace dokumentu reflektuje jeho pŕínos, tj. kvalitu, signifikanci, dopad, u Nicolaisena, 2007, s. 617). Zadruhé si při čtení citovaného úvodníku klademe otázku, co se stane s rukopisy, které citují dotčený časopis v jiné než 
„Co nejvyšší míře“. Odpovědi se nám při čtení úvodníku nedostává, ale můžeme o ní spekulovat: takové rukopisy mohou být odmítány nebo může být autorům, s odkazem na citovaný úvodník, doporučováno doplnit do textu citace dalších textů ze zmíněného časopisu. V návaznosti na to je možné se ptát, jak autoři na takové pokyny z redakce reagují, čehož se dotkneme níže.

Úryvek z editorialu v ukázce 4 je výjimečný $\mathrm{v}$ tom, že výzva $\mathrm{k}$ citování prací z určitého časopisu byla zveřejněna přímo na jeho stránkách. Přesto tato ukázka společně s dalšími dokládá, že požadavky na citování mohou být formulovány velmi explicitně.

Dosud jsme se zabývali vynucováním citací v Česku, nicméně výše popsané vynucování citací probíhá i v zahraničí. Ukázka 5 na rozdíl od té předchozí ilustruje, že vynucování citací se většinou odehrává více skrytě. Zde se jedná o e-mail směrovaný ze strany šéfredaktora na členy redakční rady mezinárodního časopisu (text překládáme z angličtiny):

Ukázka 5: Chtěli bychom zvýšit impaktový faktor časopisu [anonymizováno] a zajistit tím lepší budoucnost oboru. V tomto ohledu vás jako člena redakční rady vyzýváme, abyste ve svých publikacích citoval články dříve zveřejněné v [anonymizováno] (v případě, že zde najdete vhodné články).

Explicitní výzva citovat časopis za účelem zvýšení impaktového faktoru časopisu je typickým př́íladem komodifikace citací. Závažnost této ukázky spatřjeme $\mathrm{v}$ tom, že př́jemce e-mailu jako člen redakční rady časopisu mủže mít zájem na tom, aby časopis byl respektovaný a prestižní a rozvíjel obor, což je ale v ukázce redukováno na výši jednoho indexu. Za pozornost zde stojí skutečnost, že vynucování je rétoricky zaobaleno úsilím o budoucí blaho a rozvoj oboru spolu s dovětkem, že výzva citovat se týká pouze „vhodných článkư', čímž se šéfredaktor povrchně vztahuje také k věcné hodnotě časopisu.

Dále můžeme doložit vlastní autorskou zkušenost s prestižním zahraničním časopisem. Poté co byl rukopis pozitivně posouzen dvěma anonymními recenzenty, byli autoři rukopisu požádáni o revize vyplývající z posudků a současně byl v průvodním dopisu obsažen následující text podepsaný hlavními editory časopisu (text překládáme $z$ angličtiny):

Ukázka 6: Jak víte, mezinárodní časopisy jsou v mnoha zemích hodnoceny podle jejich důležitosti pro akademickou obec, což se většinou měří počtem citací publikovaných článků. Vzhledem k tomu, že jste si vybrali [anonymizováno] jako vhodný časopis pro svůj prríspěvek, zjevně se domníváte, že vaše téma pokračuje v debatách, které zde byly dříve vedeny. Žádáme proto, abyste se vrátili $\mathrm{k}$ předchozím číslům [anonymizováno] a (a) zajistili, že vaše rešerše literatury prostřednictvím citací zasazuje váš současný rukopis do souboru poznatků prezentovaných $\mathrm{v}$ předchozích článcích publikovaných v [anonymizováno], a (b) aby vaše závěry jasně uváděly, jak váš článek přispívá k tomuto předchozímu souboru znalostí. Vyhledávání starších článků je velmi snadné, jděte do archivu [anonymizováno], kde jsou uvedeny všechny př́spěvky publikované od roku 1992. 
Podobně jako v ukázce 5 i zde editor nejprve redukuje důležitost časopisu pro akademickou obec na počet citací (srov. Muller, 2020) a následně vyslovuje předpoklad, že posuzovaný rukopis pokračuje $\mathrm{v}$ debatách vedených na stránkách časopisu. To lze považovat za překvapivé, protože rukopis úspěšně prošel redakčním čtením a prvním kolem recenzního řízení. Z kladného výsledku těchto posouzení lze vyvodit, že „debaty, které zde byly dříve vedeny“, reflektoval. V e-mailu z redakce následuje žádost o doplnění dalších citací předchozích článků z časopisu, která je podobně jako v ukázce 5 schována pod pláštíkem snahy o budování svébytného diskurzu odehrávajícího se na stránkách předmětného časopisu. Pro př́pad, že by adresát e-mailu nevěděl, jak najít studie publikované v časopise, kam odeslal svůj rukopis k posouzení, odkazuje editor na elektronický archiv časopisu. Podobně jako u předchozích ukázek i zde dochází vynucováním citací k jejich komodifikaci, na druhou stranu editor v ukázce 6 zexplicitňuje také věcnou stránku citací, tj. př́spěvek do probíhajících oborových debat vedených na stránkách prestižního časopisu.

Z ukázek 5 a 6 není zřejmé, jak běžné je vynucování citací ze strany redakcí odborných časopisů, nicméně některé zahraniční studie naznačují, že naše zkušenosti nejsou zdaleka ojedinělé. Wilhite a Fong (2012) na základě dotazníku rozeslaného 6672 výzkumníkům v různých oborech získali informace o publikační praxi v 832 časopisech. Následně označili 175 časopisů, v nichž se editoři nebo recenzenti zapojili do vynucování citací. Wilhite a Fong (2012, s. 542) současně popsali tři znaky, na základě kterých je možné tvrdit, že se ze strany editora časopisu jedná o vynucování citací: (a) z recenzních posudků nevyplývá, že by v rukopisu chyběla nějaká citace, (b) editor neuvádí konkrétní texty ani autory, které by bylo třeba citovat, (c) editor pouze $\mathrm{v}$ obecné rovině žádá o doplnění citací z předmětného časopisu. Wilhite a Fong (2012) také upozorňují, že vynucování citací 86 \% oslovených výzkumníků považuje za nevhodné a možná právě proto je vynucování citací editory časopisů více zacíleno na níže postavené výzkumníky a méně početné autorské týmy. S odkazem na ukázku 6 se navíc nabízí otázka, zda také není vynucování citací zacíleno zejména na autory ze zemí, které nejsou na stránkách časopisu silně zastoupeny. V novějším textu Fong a Wilhite (2017) dospěli k překvapivému zjištění: ukázalo se, že vynucování citací praktikují zejména časopisy prestižní a vysoce postavené v citačních metrikách. Tuto skutečnost dokresluje také naše zkušenost s časopisem z ukázky 6 , který je považován za všeobecně uznávaný v př́slušném oboru, současně je zařazen do databáze Web of Science, má míru akceptovaných př́íspěvků okolo $20 \%$ a vydává jej Taylor and Francis.

Pokud jde o reakce autorů na vynucování citací ze strany redaktorů vědeckých časopisů, Fong a Wilhite (2017) uvádějí, že 40 \% autorů by automaticky přidalo nadbytečné citace již př̀ed zasláním rukopisu do redakce, pokud 
by věděli, že časopis praktikuje vynucování citací. Z existujících doporučení i z vlastních zkušeností s publikováním $\mathrm{v}$ tuzemsku i v zahraničí víme, že volba odborného časopisu pro odeslání rukopisu k recenzi a publikaci není snadná. Doktorandům a začínajícím pracovníkům bývá doporučováno brát v úvahu především časopisy publikující studie na dané téma, které jsou v odborné komunitě uznávány a v nichž probíhá oboustranně anonymní recenzní ŕízení (peer-review). Jako jeden z dalších způsobů, jak vybrat vhodný odborný časopis, bývá uváděn rozbor vlastní výchozí bibliografie a citovaných textů v připravovaném rukopisu - tak je možné identifikovat časopis, který publikuje podobně tematicky a metodologicky zaměřené práce (např. Belcher, 2009, s. 113). I když do hry vstupuje řada dalších faktorů, které leží mimo záběr naší studie, je třeba zdůraznit, že doporučení v jádru zní volit časopis podle tematického a metodologického zaměření studie, a tedy i citovaných textů, a nikoliv obráceně, tedy citovat texty podle vybraného časopisu.

$\mathrm{V}$ české pedagogice je situace poněkud složitější v tom, že přední pedagogické časopisy se od sebe ve svém zaměření př́liš neodlišují (Mareš \& Honsnejmannová, 2011; Juhaňák, 2017) a v praxi se setkáváme s tím, že pokud nejde o prŕíspěvek do monotematického čísla, volí autoři časopis spíše podle toho, kde ještě nepublikovali, případně podle dalších kritérií, jako je např́iklad obvyklá délka recenzního řízení, zařazení v databázích nebo možnost publikovat studii v elektronické podobě ještě před samotným vydáním čísla (articles in press). Právě v tomto prostředí se mohou objevovat výzvy jako např́klad ta z ukázky 4, ve kterých editoři vědeckých časopisů nepokrytě apelují na autory článků, aby citovali články vydané v jejich časopise, což je považováno za jednu z často kritizovaných eticky sporných praktik (Martin, 2013).

S odkazem na výše uvedené se jeden z autorů studie rozhodl podat univerzitní Etické komisi [anonymizováno] žádost o zaujetí stanoviska k úvodníku z ukázky 4. Argumentace, že se jedná o eticky spornou praktiku, byla podložena vyjádřením a doporučením Výboru pro publikační etiku $(\mathrm{COPE})^{10}$. Vypořádání podnětu bylo následující:

Ukázka 7: Z pověření předsedy Etické komise [anonymizováno] Vám sděluji, že Etická komise [anonymizováno] prostudovala Váš podnět a po rozsáhlé diskusi na zasedání rozhodla neprojednávat porušení či neporušení Etického kodexu akademických a odborných pracovníků [anonymizováno]. Etická komise zároveň požádala příslušného prorektora, aby s vedoucím redaktorem časopisu [anonymizováno] projednal otázky etiky publikování.

10 https://publicationethics.org/files/u661/Forum\%20discussion\%20topic_final.pdf 
Ukázka 7 dokládá, že Etická komise [anonymizováno] se problému vynucování citací na svém jednání věnovala. Vyjádření komise je možné mimo jiné interpretovat tak, že vynucování citací není v rozporu s Etickým kodexem akademických a odborných pracovníků [anonymizováno], nebot’ etický kodex o problému vynucování citací nepojednává. Druhá část vyjádření akcentující potřebu „projednat otázky etiky publikování" s editorem dotčeného časopisu nicméně naznačuje, že úvodník z ukázky 4 nebyl z hlediska publikační etiky zcela $\mathrm{v}$ pořádku. Vyjádření Etické komise obnažuje poměrně zásadní věc: působnost komise je (zde) redukována pouze na př́ipady jednoznačně definované Etickým kodexem. Stanovisko v podstatě rríká, že Etická komise [anonymizováno] jakékoli podněty směřující mimo rámec Etického kodexu nebude projed návat na svém zasedání, nicméně v př́ípadech, kdy komise uzná za vhodné, bude prostř́ednictvím „př́slušného prorektora“ edukovat vědce v oblasti publikační etiky.

Domníváme se, že vyjádření z ukázky 7 může být problematické ze dvou důvodů. Aby byla etická komise funkční, musela by se systematicky vypořádávat s neustále se vyvíjejícími oblastmi vědecké činnosti, které s sebou nesou i nové praktiky, kterými se vědci mohou dopouštět prohřešků vůči etice. $\mathrm{V}$ důsledku to může znamenat nutnost průběžně aktualizovat etický kodex př́slušné instituce. Vedle toho je také tř̌eba počítat s vysokou časovou náročností individuálního vzdělávání pracovníků v oblasti vědecké a publikační etiky ze strany etické komise. Redukce působnosti etických komisí pouze na př́pady porušující etické kodexy pasuje komise do role arbitrů naprosto očividných etických pochybení. Kultivační role etické komise se v tomto pojetí vytrácí.

Způsoby, jak vynucovat citace $\mathrm{k}$ navýšení citačních indexů jednotlivců, týmů nebo časopisů, mohou zahrnovat ústní nebo písemné výzvy k citování, které běžně probíhají na různých setkáních, e-mailem nebo na vědeckých konferencích, nebo přímo na stránkách časopisů, jak dokládají ukázky 2-6 (podobné zjištění ze zahraničí uvádí též Martin, 2016). Za zvláštní případ vynucování citací lze považovat pobídky k vzájemnému citování, které hraničí se zakládáním citačních kartelů, kterým se věnujeme v dalším oddíle.

\section{Zakládání citačních kartelů}

Otázku členky redakční rady jednoho z časopisů z ukázky 1, kterou jsme uvedli v části textu o citování, lze interpretovat také jako výzvu k založení citačního kartelu mezi českými pedagogickými časopisy. Jako citační kartel (též klan, bratrstvo, gang nebo ostrůvek) se označuje skupina vědců, pracovišt' nebo časopisů, kteří na sebe v publikovaných dílech vědomě, účelově, nadměrně a neodůvodněně odkazují, čímž navyšují počet citací či citační indexy 
jednotlivců nebo časopisů. Zatímco v ukázce 1 se jedná o kartel na úrovni časopisů, ukázka 8 naznačuje, jak mohou citační kartel v menším měřítku založit také jednotlivci.

Ukázka 8: Jeden odborný asistent zjistil, že pro zahájení habilitačního řízení nemá dostatek citací. Začal proto kolegům z jiných univerzit rozesílat e-maily se svými pracemi a vyzýval je, aby ho citovali a citace mu následně oznámili. To vše s př́slibem, že na oplátku bude i on jejich práce citovat. Během zhruba dvou let nasbíral dostatečný počet citací, aby mohl žádost o habilitaci podat, a nyní je docentem.

Ukázka poskytuje důkaz, že založení citačního kartelu může být rychlé, relativně snadné a účinné. Nabídka citovat něčí práci s př́slibem, že na oplátku bude i citující autor citován, může být pro mnohé lákavá. Takto vzniklý kartel rychle vygeneroval potřebné citace, které následně mohly být směněny (ze strany rozesílatele e-mailu, ale nejspíše také i ze strany adresátů) za získání vyšší akademické kvalifikace. Připomeňme, že podobně jako tomu bylo u vynucování citací, i zde se citace stává cennou komoditou, zatímco užitná hodnota citací se vytrácí. Ukázka 8 dokládá i to, že založení kartelu může pomoci akademikovi, který by jinak patrně na kvalifikační postup nedosáhl nebo byl s to postupu dosáhnout za delší dobu, získat titul docenta, který jej opravňuje vykonávat další akademické úkoly, např́klad garantovat magisterský nebo doktorský studijní program, být členem habilitačních komisí nebo vést větší množství doktorandů. Jsme přesvědčeni, že člověk, který se k vyšší kvalifikaci dostal založením kartelu, nejedná v souladu s mertonovským vědeckým étosem a jeho působení v akademické sféře může být problematické. Je např́klad dost možné, že docent citovaný v ukázce 8 mohl posuzovat práci nebo být členem habilitační komise $\mathrm{v}$ ř́zení jiného akademika z ním vytvořeného kartelu, čímž by se dostal do střetu zájmů, jelikož by měl posuzovat odraz své vlastní eticky sporné činnosti.

Nutno podotknout, že ukázka 8 není ojedinělým př́íladem. Výzvy k vzájemnému citování se ale zpravidla odehrávají více skrytě, obvykle ústní formou. Je na místě ptát se, zda je vůbec vhodné kvalifikační postup paušálně podmiňovat dostatečným počtem citací, nebot' se může jednat o požadavek motivující k neetickému chování. Muller (2020, s. 74) doporučuje nahrazovat citační metriky prostým „profesním úsudkem“ vzešlým z propracovanější formy oponentury využívající, mimo jiné, také „užitečná čísla shromážděná z citačních databází“; tato čísla by ale měla podle autora pouze dokreslovat úsudek založený na dlouhodobé profesní zkušenosti. Takové postupy se již smysluplně uplatňují, např́íklad na Vídeňské univerzitě (Gorraiz, Wieland, \& Gumpenberger, 2016) ${ }^{11}$.

11 Děkujeme anonymnímu recenzentovi za odkaz na tento text. 
Na úrovni časopisů byly první citační kartely odhaleny v prírodních vědách již v 70. letech minulého století. Na základě analýzy robustních datových souborů je možné tyto praktiky prokazovat, nebot' (sebe)citovanost časopisu by v čase měla být přibližně stejná. Jakmile nastane nějaký zásadní výkyv, je to podezřelé (Abt, 2000). Současně ale vysoká vzájemná spolupráce anebo vzájemná citovanost nemusí nutně znamenat citační kartel (Wallace et al., 2012), proto jsou citační kartely velmi obtížně rozpoznatelné a je také velmi obtížně stanovit hranici, kde končí přirozená tendence vědců citovat relevantní práce a kde začíná účelovost. Např́iklad když se vědci zabývají úzkým tématem, odkazují na sebe zcela přirozeně.

I přes výše uvedené je možné dohledat několik studií, které se na odhalování citačních kartelů zaměřily a vyslovily závažné podezření naznačující jejich existenci. Münich (2012) popsal prrípad tř́ litevských ekonomických časopisů, které se záměrně a intenzivně navzájem citují, čímž výrazně navyšují hodnotu vlastního impakt faktoru. Přesto jsou dle Münicha (2012, nestr.) „mezinárodně bezvýznamné a publikují články vědecké hodnoty často blízké nule“. Heneberg (2016) odhalil obdobnou publikační praxi u tř́ rumunských časopisů spadajících do oboru fyzika na základě mimořádně zvýšené vzájemné citovanosti časopisů zapojených do kartelu záhy poté, co byly časopisy zařazeny do databáze Web of Science. Citační kartely na úrovni časopisů může maskovat účelové vydávání tematicky propojených monočísel (Martin, 2016), zařazování osvětových či přehledových editorialů (Foo, 2011) nebo publikování přehledových studií zacílených na mapování článků v citačně spřáteleném časopisu (Van Noorden, 2013). K odhalování a vizualizaci citačních kartelů se používají speciální diagramy vyjadřující proudy citací mezi různými časopisy v určitém čase (např. aluviální nebo Sankeyovy diagramy; srov. Van Noorden, 2013). Ačkoli byla většina ze zmiňovaných citačních kartelů prokázána a dotčené časopisy byly posléze z databáze Web of Science vyřazeny (Davis, 2017), vědci publikující v těchto časopisech výrazně navýšili finanční př́ijmy svých mateřských institucí plynoucí z publikací a uspíśili také své akademické i kariérní postupy. I zde se tedy naplno projevila komodifikace citací.

\section{Diskuse a závěry}

Ve studii jsme podrobněji rozkryli některé eticky sporné citační praktiky. Ukázali jsme, že vynucování citací může probíhat spíše neformálně e-mailem nebo ústně jako výčitka necitování (ukázky 2 a 3) nebo jako explicitní výzva ze strany redakce časopisu směrem $\mathrm{k}$ autorům $\mathrm{v}$ úvodníku nebo $\mathrm{v}$ průvodním e-mailu od editora (ukázky 4 a 6 ), př́padně od editora směrem ke členům redakční rady časopisu (ukázka 5). Pokud jde o zakládání citačních kartelů, 
doložili jsme dvě výzvy od jednotlivců ke členům vědecké komunity (ukázka 1 a 8). Co je společné všem těmto praktikám, je komodifikace citací: z toho, že jeden autor cituje druhého, se ve všech uvedených př́kladech vytrácí užitná hodnota citací, která je nahrazována možností vyměnit citaci za něco jiného, např́ílad kariérní postup jednotlivce, finanční odměnu nebo zvýšení citačních indexů časopisu (srov. Engeström, 2015, s. 67-70). Tím jednání vědce přestává být nestranné, transparentní a kritické, a zároveň se do vědecké práce začínají promítat jiné než čistě vědecké zájmy. Praktiky, jako je vynucování citací nebo zakládání citačních kartelů, tak rozkládají Mertonův vědecký étos, a považujeme je proto za neetické.

Protože pojímáme praktiky jako pozorovatelné jednání, není možné usuzovat na motivy aktérů, př́padně na to, zda a do jaké míry jsou si aktéŕi v ukázkách vědomi problematičnosti a závažnosti svého jednání. Hranice mezi nevědomostí a kalkulem je téměř neviditelná a eticky hraniční jednání je vždy možné s využitím selektivně vybraných argumentů obhájit či racionalizovat (Bandura, 2002).

Pokud odhlédneme od psychologizace jednání jednotlivých aktérů, je možné o zde prezentovaných praktikách uvažovat ve vztahu k prostředí, ve kterém vznikají a které může realizaci eticky sporného jednání katalyzovat nebo naopak potlačovat. Obecně lze říci, že systém hodnocení vědy, mechanismy rozdělování finanční podpory na vědu a některé kompetitivně nastavené institucionální politiky vytvářejí prostředí, které může vědce svádět ke hledání zkratek, např́íklad vynucováním citací a zakládáním citačních kartelů, jak jsme doložili v této studii. Kámen úrazu spatřujeme především v redukcionistickém pohledu na kvalitu vědecké práce, kdy se namísto odborného úsudku spoléhá na číselné indikátory, jako jsou počty citací, h-indexy nebo impaktové faktory. Jak uvádí Muller (2020, s. 29), „,cokoliv, co lze měřit a odměňovat, bude manipulováno“. Pokud bychom se měli zaměřit konkrétně na prostř̌edí Masarykovy univerzity, na které oba působíme a z níž řada zde prezentovaných ukázek pochází, mủžeme uvést řadu formalizovaných pravidel, která mohou eticky závadné jednání podněcovat. $V$ př́padě habilitačních řízení, která pro odborného asistenta představují leckde požadovaný kariérní postup ${ }^{12}$, lze na př́kladu Pedagogické fakulty Masarykovy univerzity uvést explicitní požadavek na minimálně dvě publikace $\mathrm{v}$ databázích Web of Science či Scopus a současně minimálně 20 domácích a zahraničních citací (Směrnice děkana..., 2018). Počty citací jsou součástí

12 Pro garanci základního teoretického předmětu v magisterském studiu je požadován minimálně docentský titul (Nař̌zeni vlády, 2016). 
personálních listů pro účely akreditací; citace se rovněž vnitroinstitucionálně uvádějí jako podklad k výběru publikací zasílaných do Modulu 1 hodnocení dle Metodiky hodnocení výzkumných organizací (srov. Metodika..., 2017). Tyto a další požadavky mohou vést $\mathrm{k}$ tomu, že autoři začnou vynucovat citace nebo zakládat citační kartely. Protipólem těchto politik, které mohou vést vědce k eticky spornému jednání, by měla být činnost etických komisí. Nicméně jak jsme uvedli v ukázce 7, působnost Etické komise [anonymizováno] v této oblasti, zdá se, je omezena pouze na Etický kodex akademických a odborných pracovníků [anonymizováno], který se oblasti vynucování citací nebo citačních kartelů vůbec nedotýká.

Stav, kdy vědecká komunita tiše toleruje projevy porušování publikační etiky, může být pro poctivé vědce frustrující. Na vědeckém výsluní se totiž vedle výjimečných vědců mohou ocitat také lidé, kteří se domnívají, že je v pořádku vytvářet citační kartely nebo vynucovat citace s cílem obejít požadavek dělat poctivou, náročnou a kvalitní vědu. Uvedené projevy porušování publikační etiky degradují akademickou kulturu až do té míry, že se na některých pracovištích mohou stát běžným standardem. I přes výše nastíněnou skepsi k vykazování počtů citací a citačních indexů je třeba dodat, že analýzy citačních sítí mohou poskytovat užitečné informace pro reflexi i rozvoj vědních oborů (Ding, 2011). Protože citační databáze mají nedocenitelný význam např́ílad pro analýzu trendů a predikci vědeckého vývoje, je nezbytné, aby citační záznamy měly co nejvyšší vypovídající hodnotu. Vynucování citací nebo zakládání citačních kartelů tedy v důsledku vede $\mathrm{k}$ pokřivení a erozi vědy namísto jejího rozvíjení.

Ve studii jsme pojednali o vynucování citací a zakládání citačních kartelů za použití vlastních dat a prvkủ autoetnografického př́stupu. Protože v českém prostředí dosud neexistuje empiricky podložené pojednání o těchto praktikách, může tato studie představovat výchozí bod k dalšímu bádání v této oblasti. Dosud nevíme, jak běžné uvedené praktiky jsou, ani nejsou zmapovány jejich dopady na českou odbornou komunitu obecně, ani v jednotlivých oborech. Ve studii jsme se dotkli i regulační role etických komisí v této oblasti. Je to právě činnost orgánů, které by na dodržování publikační etiky měly dohlížet (zejména etické a disciplinární komise), problematika autocitací nebo citování ve vztahu doktorand-školitel nebo podřízený-nadřízený, na které by bylo vhodné se v budoucím úsilí o kultivaci publikačních a citačních postupů zaměritit.

Závěrem zbývá formulovat doporučení pro eticky přijatelnou publikační praxi. Klíčové, ovšem nikoli dostačující, je odkázat na doporučení publikačního manuálu APA (American Psychological Association, 2020, s. 253), které uvádí: „Citujte práci osob, jejichž myšlenky, teorie nebo výzkum přímo ovlivnily vaši práci.“ Asi bychom nevytvořili jiná a lepší doporučení, než která představil Penders (2018). V př́loze článku jednotlivá doporučení 
Penderse parafrázujeme a obohacujeme je vlastními komentáři vyplývajícími z námi prezentovaných výzkumných zjištění. Jsme si vědomi, že výše uvedená doporučení reprezentují ideál, ale přxesto jsou realistická a dosažitelná. V neposlední řadě apelujeme na výzkumníky, aby si byli vědomi skutečnosti, že každá citace legitimizuje vědeckou hodnotu citovaného díla a spoluutváří vědecké pole. $V$ př́padě, že je citované dílo nekvalitní, nepřispívá jeho citování $\mathrm{k}$ rozvoji relevantní a společensky zodpovědné vědy. Také věříme, že mluvením a psaním o citační etice je možné výzkumnou komunitu kultivovat a některé aspekty publikování tak zvědomovat.

\section{Poděkování}

Děkujeme dvěma anonymním recenzentům za konstruktivní náměty a připomínky, jež nás donutily ke studiu i k zamyšlení a výrazně tak přispěly k eliminaci slabých míst v původní verzi rukopisu.

\section{Literatura}

Abt, H. (2000). Do important papers produce high citation counts? Scientometrics, 48(1), 65-70. https://doi.org/10.1023/A:1005680318379

Aksnes, D. W., \& Rip, A. (2009). Researchers' perceptions of citations. Research Policy, 38(6), 895-905. https://doi.org/10.1016/j.respol.2009.02.001

American Psychological Association (2020). Publication manual (7. vyd.). American Psychological Association. https://doi.org/10.1037/0000165-000

Anderson, L. (2006). Analytic autoethnography. Journal of Contemporary Ethnography, 35(4), 373-395. https://doi.org/10.1177/0891241605280449

Aristotelés (1996). Etika Nikomachova. Rezek.

Artino Jr, A. R., Driessen, E. W., \& Maggio, L. A. (2019). Ethical shades of gray: International frequency of scientific misconduct and questionable research practices in health professions education. Academic Medicine, 94(1), 76-84. https://doi.org/10.1097/ ACM.0000000000002412

Atkinson, P., \& Hammersley, M. (2007). Ethnography: Principles in practice (3. vyd.). Routledge.

Auer, P. (2014). Jazyková interakce (J. Nekvapil, P. Kaderka, M. Nekula, V. Dovalil, I. Vasiljev, \& M. Sloboda, Přel.). Nakladatelství Lidové noviny.

Baccini, A., De Nicolao, G., \& Petrovich, E. (2019). Citation gaming induced by bibliometric evaluation: A country-level comparative analysis. PloS One, 14(9), e0221212. https:// doi.org/10.1371/journal.pone.0221212

Bajerski, A., \& Siwek, T. (2012). Bibliometrická analýza české geografie v databázi Scopus. Geografie, 117(1), 52-71.

Bandura, A. (2002). Selective moral disengagement in the exercise of moral agency. Journal of Moral Education, 31(2), 101-119. https://doi.org/10.1080/0305724022014322 
Belcher, W. L. (2009). Writing your journal article in 12 weeks: A guide to academic publishing success. SAGE.

Bentham, J. (1996). An introduction to the principles of morals and legislation: The collected works of Jeremy Bentham. University Press.

Bezdíček, O., Preiss, M., \& Dočkalová, E. (2009). Publikační aktivita a citovanost 85 českých aktivních profesorů a docentů v oboru psychologie: revize a odpověd' na kritiku. Psychiatrie, 13(2-3), 108-113.

Bourdieu, P. (2010). Pravidla uméní: geneze a struktura literárníbo pole. Host.

Davis, P. (2017, May 30). How much citation manipulation is acceptable? The Scholarly Kitchen. https://scholarlykitchen.sspnet.org/2017/05/30/how-much-citation-manipulation-isacceptable/

Ding, Y. (2011). Scientific collaboration and endorsement: Network analysis of coauthorship and citation networks. Journal of Informetrics, 5(1), 187-203. https://doi.org/1010.1016/j. joi.2010.10.008

Dvořáčková, J., Pabian, P., Smith, S., Stöckelová, T., Šima, K., \& Virtová, T. (2014). Politika a každodennost na českých vysokých školách: etnograficképobledy na vždélávání a výzkum. Sociologické nakladatelství SLON.

Dvořáková, K. (2017). Ty jo, to seš dobrá! Jak se skeládaji komplimenty v čeśtině. Academia.

Engeström, Y. (2015). Learning by expanding: An activity-theoretical approach to developmental research (2. vyd.). Cambridge University Press. https://doi.org/10.1017/CBO9781139814744

Fong, E. A., \& Wilhite, A. W. (2017). Authorship and citation manipulation in academic research. PloS One, 12(12), e0187394. https://doi.org/10.1371/journal.pone.0187394

Foo, J. Y. A. (2011). Impact of excessive journal self-citations: A case study on the Folia Phoniatrica et Logopaedica journal. Science and Engineering Ethics, 17(1), 65-73. https://doi. org/10.1007/s11948-009-9177-7

Garfield, E. (2006). The history and meaning of the journal impact factor. Jama, 295(1), 90-93. https://doi.org/10.1001/jama.295.1.90

Gaus, G. (2003). Dirty hands. In R. G. Frey \& Ch. Wellman (Eds.), A companion to applied ethics (s. 167-179). Blackwell. https://doi.org/10.1002/9780470996621

Gorraiz, J., Wieland, M., Gumpenberger, C. (2016). Individual bibliometric assessment at University of Vienna: From numbers to multidimensional profiles. El Profesional de la Información, 25(6), 901-914. https://doi.org/10.3145/epi.2016.nov.07

Grant, D. B., Kovács, G., \& Spens, K. (2018). Questionable research practices in academia: Antecedents and consequences. European Business Review, 30(2), 101-127. https://doi. org/10.1108/EBR-12-2016-0155

Haley, M. R. (2017). On the inauspicious incentives of the scholar-level h-index: An economist's take on collusive and coercive citation. Applied Economics Letters, 24(2), 85-89. https:// doi.org/10.1080/13504851.2016.1164812

Heneberg, P. (2016). From excessive journal self-cites to citation stacking: analysis of journal self-citation kinetics in search for journals, which boost their scientometric indicators. PloS One, 11(4), e0153730. https://doi.org/10.1371/journal.pone.0153730

Hirsch, J. E. (2005). An index to quantify an individual's scientific research output. Proceedings of the National Academy of Sciences, 102(46), 16569-16572. https://doi.org/10.1073/ pnas.0507655102

Hyland, K. (1999). Academic attribution: Citation and the construction of disciplinary knowledge. Applied Linguistics, 20(3), 341-367. https://doi.org/10.1093/applin/20.3.341 
Hyland, K. (2004). Disciplinary discourses: Social interactions in academic writing. University of Michigan Press.

Chubin, D. E., \& Moitra, S. D. (1975). Content analysis of references: Adjunct or alternative to citation counting? Social Studies of Science, 5(4), 423-441. https://doi. org/10.1177/030631277500500403

John, L. K., Loewenstein, G., \& Prelec, D. (2012). Measuring the prevalence of questionable research practices with incentives for truth telling. Psychological Science, 23(5), 524-532. https://doi.org/10.1177/0956797611430953

Juhaňák, L. (2017). Sociální sítě autorů publikujících v pedagogických vědách v letech 2009-2013: exploratorní analýza. Studia paedagogica, 22(1), 9-36. https://doi.org/10.5817/ SP2017-1-2

Kouba, K. (2011). Publikační výsledky českých kateder politologie a mezinárodních vztahů a jejich výzkumníků v citačních databázích (1990-2010). Politologický časopis-Czech Journal of Political Science, 18(4), 354-378.

Lăzăroiu, G. (2013). On citation ethics: Editorial shenanigans to boost impact factor. Contemporary Readings in Law and Social Justice, 5(1), 82-87.

Mareš, J., \& Honsnejmannová, I. (2011). Diskuse o pedagogických časopisech v České republice. Pedagogická orientace, 21(1), 104-113.

Martin, B. R. (2013). Whither research integrity? Plagiarism, self-plagiarism and coercive citation in an age of research assessment. Research Policy, 42(5), 1005-1013. http://dx.doi. org $/ 10.1016 /$ j.respol.2013.03.011

Martin, B. R. (2016). Editors' JIF-boosting stratagems - Which are appropriate and which not? Research Policy, 45(1), 1-7. http://dx.doi.org/10.1016/j.respol.2015.09.001

Merton, R. K. (1968). The Matthew effect in science: The reward and communication systems of science are considered. Science, 159(3810), 56-63. https://doi.org/10.1126/science. 159.3810 .56

Merton, R. K. (1973). The normative structure of science. In R. K. Merton (Ed.), The sociology of science: Theoretical and empirical investigations (s. 267-278). University of Chicago Press.

Metodika hodnoceni výzkumných organizaci a hodnoceni programu účlové podpory výzkumu, vývoje a inovací (2017). Úřad vlády České republiky.

Muller, J. Z. (2020). Tyranie metrik (J. Zlatuška, Přel.). Academia.

Münich, D. (2012, May 13). Citační bratrstva. http://blog.aktualne.cz/blogy/daniel-munich. php?itemid $=16396$

Narízeni vlády o standardech pro akreditace ve vysokém školství. 274/2016 Sb. (2016). https://www. zakonyprolidi.cz/cs/2016-274

Nicolaisen, J. (2007). Citation analysis. Annual Review of Information Science and Technology, 41(1), 537-607. https://doi.org/10.5555/1658843.1658863

Penders, B. (2018). Ten simple rules for responsible referencing. PLoS Computational Biology, 14(4), e1006036. https://doi.org/10.1371/journal.pcbi.1006036

Petr, M. (2017). Dobrá praxe védeckého publikování. Masarykova univerzita. https://scientometrics.muni.cz/do/rect/metodika/VaV/65890653/Zasady_vedeckeho_publikovani_na_MU_ final.pdf

Phelan, T. J. (1999). A compendium of issues for citation analysis. Scientometrics, 45(1), 117-136. https://doi.org/10.1007/BF02458472

Průcha, J. (2015). Pedagogické časopisy: jejich využívání jako informačních zdrojů. Pedagogická orientace, 25(1), 122-130. http://dx.doi.org/10.5817/PedOr2015-1-122 
Průcha, J., \& Švaříček, R. (2009). Etický kodex české pedagogické vědy a výzkumu. Pedagogická orientace, 19(2), 89-105.

Psathas, G. (1995). Conversation analysis: The study of talk-in-interaction. SAGE.

Reedijk, J. (2012). Citations and ethics. Angewandte Chemie International Edition, 51(4), 828-830. https://doi.org/10.1002/anie.201107554

Sannino, A. (2008). Experiencing conversations: Bridging the gap between discourse and activity. Journal for the Theory of Social Behaviour, 38(3), 267-291. https://doi. org/10.1111/j.1468-5914.2008.00371.x

Skovajsa, M. (2014). Celková a zahraniční citovanost Sociologického časopisu: výsledky citační analýzy. Sociologický časopis / Czech Sociological Review, 50(5), 671-712. https://doi.org/10.13 060/00380288.2014.50.5.119

Smèrnice děkana č. 5/2018: Zásady babilitačního rízeneni a ríżeni ke jmenováni profesorem na Pedagogické fakultěMasarykovy univerzity. (2018). https://is.muni.cz/do/ped/VPAN/smerdek/c_5_2018_ zasasy_hab_prof.pdf

Stöckelová, T. (2009). Politická a morální ekonomie vědy. In T. Stöckelová (Ed.), Akademické poznávání, vykazováni a podnikání: etnografie mènici se české védy (s. 38-72). Sociologické nakladatelství SLON.

Stocker, M. (1992). Plural and conflicting values. Oxford University Press.

Swales, J. M. (2014). Variation in citational practice in a corpus of student Biology papers: From parenthetical plonking to intertextual storytelling. Written Communication, 31(1), 118-141. https://doi.org/10.1177/0741088313515166

Tahamtan, I., \& Bornmann, L. (2019). What do citation counts measure? An updated review of studies on citations in scientific documents published between 2006 and 2018. Scientometrics, 121(3), 1635-1684. https://doi.org/10.1007/s11192-019-03243-4

Thombs, B. D., Levis, A. W., Razykov, I., Syamchandra, A., Leentjens, A. F., Levenson, J. L., \& Lumley, M. A. (2015). Potentially coercive self-citation by peer reviewers: A crosssectional study. Journal of Psychosomatic Research, 78(1), 1-6. https://doi.org/10.1016/j.jpsychores.2014.09.015

Tomančáková, D. (2015). Citační analýza časopisu ProInflow. ProInflow, 7(2), 53-66.

Úřad vlády České republiky (2020). MŠMT, MO, MV ČR, VŠ. Protokol z.projednání výsledku Hodnocení 18 podle M17+ dne 24. 1. 2020 v 13:00 hod. https://www.vyzkum.cz/FrontClanek. aspx?idsekce $=903030 \&$ ad $=1 \&$ attid $=903115$

Van Noorden, R. (2013). Brazilian citation scheme outed. Nature, 500, 510-511. https://doi. org/doi: 10.1038/500510a

Wallace, M. L., Larivière, V., \& Gingras, Y. (2012). A small world of citations? The influence of collaboration networks on citation practices. PloS One, 7(3), e33339. https://doi. org/10.1371/journal.pone.0033339

Wilhite, A. W., \& Fong, E. A. (2012). Coercive citation in academic publishing. Science, 335(6068), 542-543. https://doi.org/10.1126/science.1212540 


\section{Kontakt na autory}

Petr Knecht

Katedra geografie, Pedagogická fakulta, Masarykova univerzita

E-mail: knecht@ped.muni.cz

František Tůma

Katedra anglistiky a amerikanistiky, Filozofická fakulta, Masarykova Univerzita

E-mail:tuma@phil.muni.cz

\section{Corresponding authors}

Petr Knecht

Department of Geography, Faculty of Education, Masaryk University

E-mail:knecht@ped.muni.cz

František Tůma

Department of English and American Studies, Faculty of Arts, Masaryk University E-mail: tuma@phil.muni.cz 


\section{Př́loha}

Doporučeni pro správnou citační praxi (zdroj: Penders, 2018, doplněno autory)

1. Citujte pouze relevantní publikace. Citace jsou pro čtenáře zdrojem informací o tom, ze kterých děl vycházíte a čí myšlenky využíváte. Citace současně poskytují důkaz o správnosti vašeho uvažování a umožňují zpětnou rekonstrukci použité argumentační linie.

2. Citujte pouze publikace, které jste četli. Bez podrobného seznámení se s citovaným dílem není možné zodpovědně rozhodnout, zda je toto dílo relevantní vzhledem k cílům práce. Bez znalosti citovaného díla může (např́k lad v důsledku citačního plagiátorství) docházet ke zkreslení vědeckého poznání.

3. Citujte pouze publikace, jejichž citování jste schopni věcně zdůvodnit. U každého z citovaných děl byste měli obhájit a vysvětlit jeho legitimitu a prŕnosnost $\mathrm{z}$ hlediska obsahu a cíle rukopisu.

4. Citujte transparentně, ne neutrálně. Zejména v prrípadě citací objasňujících teoretická východiska a v oddílech věnovaných diskusi výzkumných zjištění je nezbytné zasadit každou citaci do širšího rámce a vysvětlit, v čem spočívá hodnota, relevance a významnost citovaného díla.

5. Citujte sami sebe, pokud je to nutné. Obecně se doporučuje využívat autocitace spíše střídmě. Současně je ale korektní přiznat, že stavíte na některých vlastních myšlenkách publikovaných dříve. A to i v př́padě, že byste měli citovat sami sebe. Pouze tak je možné odlišit vědecký recyklát od originálního vědeckého díla. Autocitace jsou ale eticky problematické $\mathrm{v}$ př́padě, že sleduji jiný než vědecký cíl, např́íklad zvyšování citačních indexů.

6. Citujte všechny (předchozí) práce, které úzce souvisejí s vaším dílem. Očekává se, že provedete důkladnou rešerši literatury a ocitujete všechny práce, které přispěly $\mathrm{k}$ rozšîř́enému porozumění výzkumného problému.

7. Nezamlčujte relevantní citace. Základem publikační etiky je uznání druhých. Respekt a uznání si zaslouží každý, kdo dospěl k poznatku, který ovlivnil vaši práci. To se týká i těch, kteř́i vás ovlivnili, ale z nějakého důvodu vám nejsou sympatičtí.

8. Stanovte prioritu jednotlivých citací. Často se stává, že počet citací či rozsah publikovaných textů bývá omezen. Vědci se poté musí složitě rozhodovat, které práce jsou z hlediska citování stěžejní a které nikoli. Jako efektivní se ukazuje stanovit si prioritu citací v jednotlivých oddílech (úvod, metoda, diskuse). 
9. Hodnot'te citace podle toho, co vyjadřují. Každý odkaz na práci někoho jiného je výsledkem volby citujícího autora. Z tohoto úhlu pohledu je třeba citace také interpretovat. Z každé citace by mělo být jasné, co je jejím cílem, případně jaké tvrzení nebo myšlenku citace dokládá či rozporuje.

10. Hodnot'te citace s ohledem na jejich zasazení do širšího kontextu. Prostřednictvím citací vyjadřujete svou příslušnost $\mathrm{k}$ určitým vědeckým školám, komunitám či myšlenkovým směrům. Je nutné mít na paměti, že citacemi můžete ovlivnit (i manipulovat) uvažování čtenáře.

11. Hodnot'te citace jako součást komunikačních rámců. Citace jsou vždy součástí širšího komunikačního rámce. Neplatí vždy předpoklad, že citace článku A myšlenkově podpírá článek B. Článek B se totiž vưči citovanému článku A může vymezovat, případně zpochybňovat nějakou v něm obsaženou myšlenku. Motivy stojící v pozadí odkazu na určité dílo mohou být různé.

12. Akceptujte skutečnost, že citační zvyklosti mohou být v různých oborech odlišné. Průměrný počet citací uváděných v textech publikovaných $\mathrm{v}$ různých oborech je velmi odlišný. $\mathrm{V}$ přírodních vědách je např́iklad běžné podpírat každé exaktní tvrzení několika odkazy, v humanitních vědách se odkazuje méně, nicméně větší prostor je věnován interpretaci citovaných myšlenek a děl. 